\title{
Histological Evaluation of the Bone Repair Using Mineral Trioxide Aggregate Combined to a Material Carrier
}

\author{
Evaluación Histológica del Proceso de Reparación Ósea Utilizando \\ Agregado Trióxido Mineral Combinado a un Material Cargador
}

\begin{abstract}
"Hilmo Barreto Leite Falcão-Filho; *João Paulo Mardegan Issa; "Cássio do Nascimento; "Mamie Mizusaki Iyomasa; "Simone Cecílio Hallak Regalo; "Selma Siéssere; "Vinícius Pedrazzi \& ** Dimitrius Leonardo Pitol
\end{abstract}

FALCÃO-FILHO, H. B. L.; ISSA, J. P. M.; NASCIMENTO, C.; IYOMASA, M. M.; REGALO, S. C. H.; SIÉSSERE, S.; PEDRAZZI, V. \& PITOL, D. L. Histological evaluation of the bone repair using mineral trioxide aggregate combined to a material carrier. Int. J. Morphol., 25(4):789-796, 2007.

SUMMARY: The aim of this study was to present a possible carrier for MTA, monoolein gel, with the objective to maintain this material in the place that was inserted and verify if this procedure is able to optimize its action. The data were evaluated by histomorphometric method and submitted to statistical analysis. The histological responses observed in this study indicate that the MTA is a reliable material and should be considered effective in bone periapical defects and the monoolein gel was capable to maintain the MTA in situ.

KEY WORDS: MTA; Monoolein gel; Histomorphometry; Periapical defect.

\section{INTRODUCTION}

In some cases, root perforations can result from resorptions and carious lesions. However, this incident usually occurs during endodontic treatment and preparations for a post (Alhadainy 1994). The prognosis of a root perforation depends on its size and location, the length of time the defect has been open to the environment before sealing and the amount of periodontal irritation. The shorter the time lapse, the smaller the size and the more apical the perforation, the greater is the chance for successful treatment (Bogaerts, 1997).

In addition to the correct treatment regimen, the properties of the repair material are important. The ideal material should be able to seal the defect and should have excellent biocompatibility. Furthermore, induction of osteogenesis and cementogenesis, ease of handling and a low product price are advantageous (Hartwell \& England, 1993).

Since 1998, mineral trioxide aggregate (MTA) has been available. This product is indicated for the reparation of various root defects, apexification and direct pulp capping. Several in vitro and in vivo experiments have shown that MTA prevents leakage, is biocompatible and promotes regeneration of the original tissues when placed in contact with dental pulp or periradicular periodontium (Holland et al., 2001; Pitt Ford et al., 1996; Torabinejad \& Chivian, 1999).

MTA is a powder aggregate, containing mineral oxides (Lee et al., 1993). Besides its noncytotoxicity (Osorio et al., 1998), it has good biological action (Torabinejad et al., 1995c, d, 1998) and stimulates repair (Regan et al., 2002; Economides et al., 2003), because it allows cellular adhesion, growth and proliferation on its surface (Zhu et al., 2000). MTA consistently allows for the overgrowth of cementum, and it may facilitate the regeneration of the periodontal ligament and formation of bone (Al-Rabeah et al., 2006; Oviir et al., 2006; Schwartz et al., 1999). When used in dogs' teeth with incomplete root formation and contaminated canals, MTA often induced the formation of apical barrier with hard tissue (Tittle et al., 1996; Shabahang et al., 1999). A carrier to maintain the MTA in situ may be interesting, permitting this material acting for more time.

In thitsuraychoose the monoolein gel, a biodegradable polar lipid has no marked toxic effects (Ganem-Quintanar et al., 2000) and depending on water

\footnotetext{
* Faculty of Dentistry, University of São Paulo, Ribeirão Preto, São Paulo, Brazil.

**Biosciences Institute- Molecular and Cellular Biology (UNESP), Rio Claro, São Paulo, Brazil.
} 
content and temperature may form several phases, including reverse cubic and hexagonal ones. The reverse cubic phase of monoolein and water is formed at room temperature, and has been shown to accommodate and sustain the release of drugs with various physicochemical properties, including proteins and peptides (Lee \& Kellaway 2000 a, b; Lara et al., 2005 and Turchiello et al., 2003).

The aim of this study was to present a possible carrier for MTA, monoolein gel, with the objective to maintain this material in the place that was inserted and verify if this procedure is able to optimize its action.

\section{MATERIAL AND METHOD}

This study followed the requirements of the Ethics Committee on the Use of Animals in Experimentation at the University of São Paulo, Brazil.

Substances. The MA was obtained by Angelus, Indústria de Produtos Odontológicos Ltda, Brasil and mixture in the proportion MTA:water (1g:3mL distilled water). Monoolein (Myverol 18-99, 98.1\% monoglycerides, Naarden, The Netherlands) gel was obtained in a 7:3 (Monoolein:Water) proportion as described before (Lara et al., 2005). Briefly, monoolein was weighed and heated to $45^{\circ} \mathrm{C}$. Water in the same temperature was added and the mixture was left to rest until it became a transparent and viscous mass. MTA in water solution $(1 \mathrm{mg} / \mathrm{mL})$ was added and the mixture homogenized.

Animals. Twenty male Wistar rats $(n=20), 350 \mathrm{~g}$, were selected and allowed to acclimatize for one week prior to surgery. The animals were fed with commercial rat chow and had access to food and water ad libitum. After randomly dividing the animals into four equal groups, a circular bone defect $(2.5 \mathrm{~mm}$ of diameter) was created in the distal root of the first molar on the right hemi-mandible (Fig. 1A) of each one and filled with: animal's coagulum (Group I, n=5), monoolein gel (Group II, n=5), MTA in aqueous solution (Group III, n=5), MTA combined with monoolein gel as a carrier (Group IV, n=5).

Surgical procedure. The rats were anaesthetized with standard anesthetic cocktail consisting of ketamine hydrochloride $(60 \mathrm{mg} / \mathrm{Kg})$ and xylazine $(5 \mathrm{mg} / \mathrm{Kg})$, administered intraperitoneally. Surgery was performed using aseptic techniques. A linear incision was made through the skin, subcutaneous tissues and masseter muscle, parallel to the inferior border of the mandible. The buccal surface of the mandible was exposed and a $2.5 \mathrm{~mm}$ circular bone defect was created in the distal root of the first molar on the right hemi- mandible. This bone defect was performed using a high-speed drill, adjusted to 3000rpm, and abundant irrigation.

Sacrifice and animals' perfusion. After ten days, the animals were anaesthetized with urethane $37.5 \%(0.4 \mathrm{~mL} /$ $100 \mathrm{~g}$ ) and submitted to perfusion. This procedure involves an intracardiac infusion of saline solution $(100 \mathrm{~mL})$ followed by $10 \%$ formalin and paraformaldehyde $4 \%$ in phosphate buffer $0.2 \mathrm{M}(100 \mathrm{~mL})$. The hemi-mandibles were removed for histological processing.

Histological processing and histomorphometric analysis. The hemi-mandibular blocks were immersed in $4 \%$ paraformaldehyde/0.1M phosphate-buffer solution for $24 \mathrm{~h}$, decalcified in 5\% EDTA-TRIS for 30 days and neutralized by a $5 \%$ sodium sulphate solution. After imbedded in paraffin, the specimens were cut into $6 \mu \mathrm{m}$ thick sections following the saggital plane and stained with HematoxylinEosin and Trichrome-Masson. The histological sections of the circular bone defect were observed through a grid containing 100 equidistant points (Fig. 1B), adapted to the eyepiece of a light microscope (Leica DMRB, Germany) connected to a digital camera (Olympus DP11, USA), to measure the percentage of components of the new tissue by a differential point-counting method (Weibel et al. 1966). Two thousand points in ten fields lying onconnective tissue and bone trabeculae were counted per animal considering the bone defect area.

Statistical analysis. Data analysis for new bone formation was performed by GLM ANOVA with Tukey test, with $95 \%$ of significance level.

\section{RESULTS}

Clinical findings. One animal belonged to the group MTA+monoolein gel, exhibited a slight swelling and inflammatory response, which was considered to be postoperative infection (Fig. 1C, 1D). Other animals showed uneventful healing.

Histological observations. The histological data obtained are shown in Table I. We can observe that there was found more new bone formation in both groups that the MTA was applied, without statistical difference between them ( $>>0.05)$ and more newly formed bone in the group that the MTA was combined with monoolein gel as a carrier. These groups presented statistical difference (Fig. 2A and 2B) in relation to the other two groups, bone defect filled by animals' coagulum and monoolein gel (Fig. 2C and 2D), where it was found a little quantity of newly formed bone $(\mathrm{p}<0.05)$. 

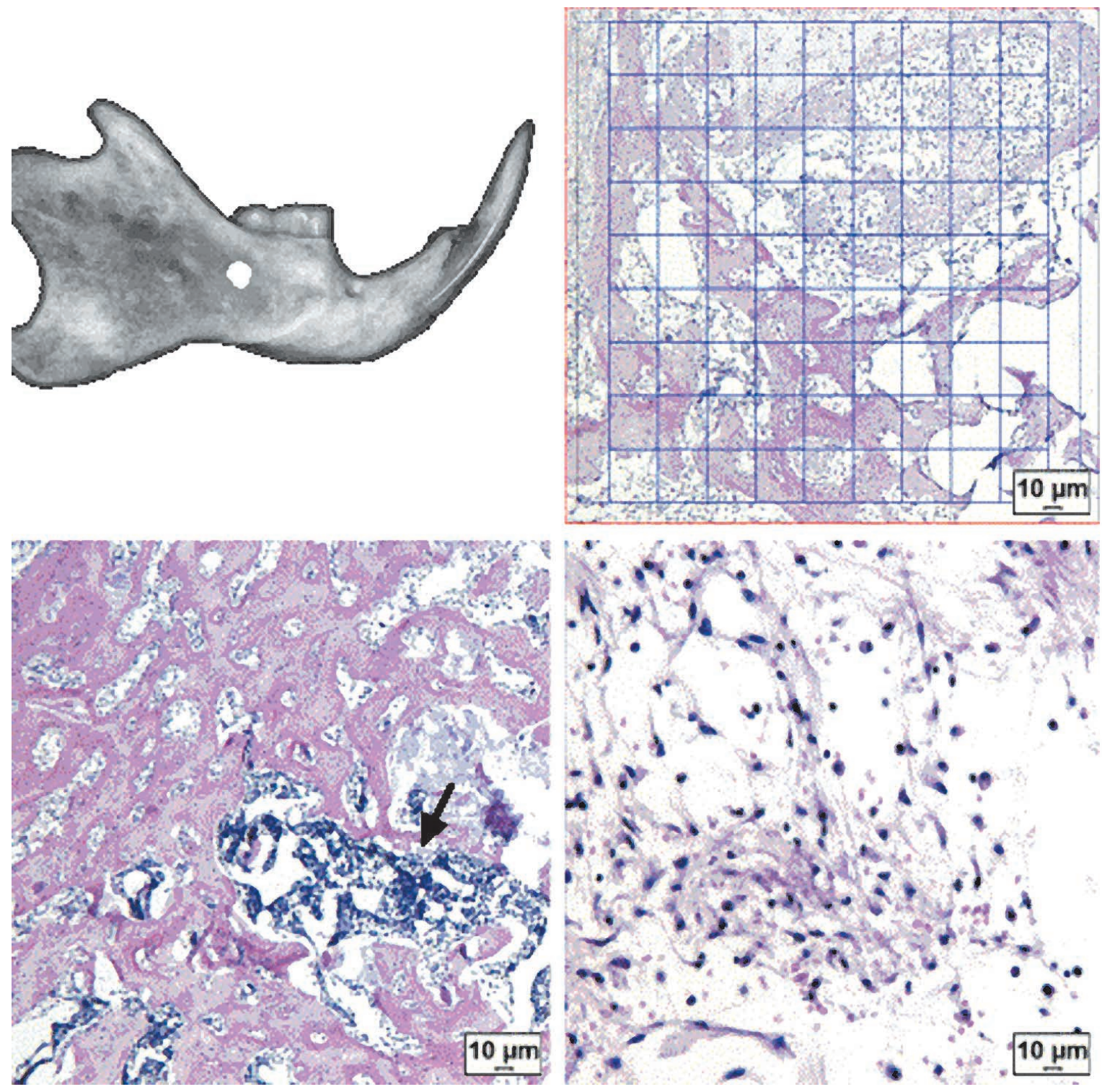

Fig. 1. A. Schematic drawing of the bone defect in the distal region of the molar tooth; B. Representative photomicrograph of the histomorphometric method used for the quantification of newly formed bone (125X of original magnification, Hematoxylin-Eosin); C. Representative photomicrograph showing the inflammatory process (arrow) inserted in the newly formed bone (125X of original magnification, Hematoxylin-Eosin); D. Representative photomicrograph showing the inflammatory cells characterized by plasmocytes, lymphocytes, and macrophages (125X of original magnification, Hematoxylin-Eosin).

Table I. Means (M) and standra deviation (SD) of the four studied groups.

\begin{tabular}{ccc}
\hline Groups & Mean $(\mathrm{M})$ & Standar deviation (SD) \\
\hline $\mathrm{I}^{\mathrm{a}}$ & 28.77 & 3,34 \\
$\mathrm{II}^{\mathrm{a}}$ & 31.71 & 6.58 \\
III $^{\mathrm{b}}$ & 45.30 & 5.41 \\
IV $^{\mathrm{b}}$ & 47.26 & 7.76 \\
\hline
\end{tabular}

a.b. Different letters show statistical difference $(\mathrm{p}<0.05)$.

\section{DISCUSSION}

The objective of this study was to present a possible carrier for MTA, monoolein gel, with the objective to maintain this material in the place that was inserted and verify if this procedure is able to optimize its action.

In this study, it was made a circular defect in the distal region of the molar tooth, simulating a defect lesion 

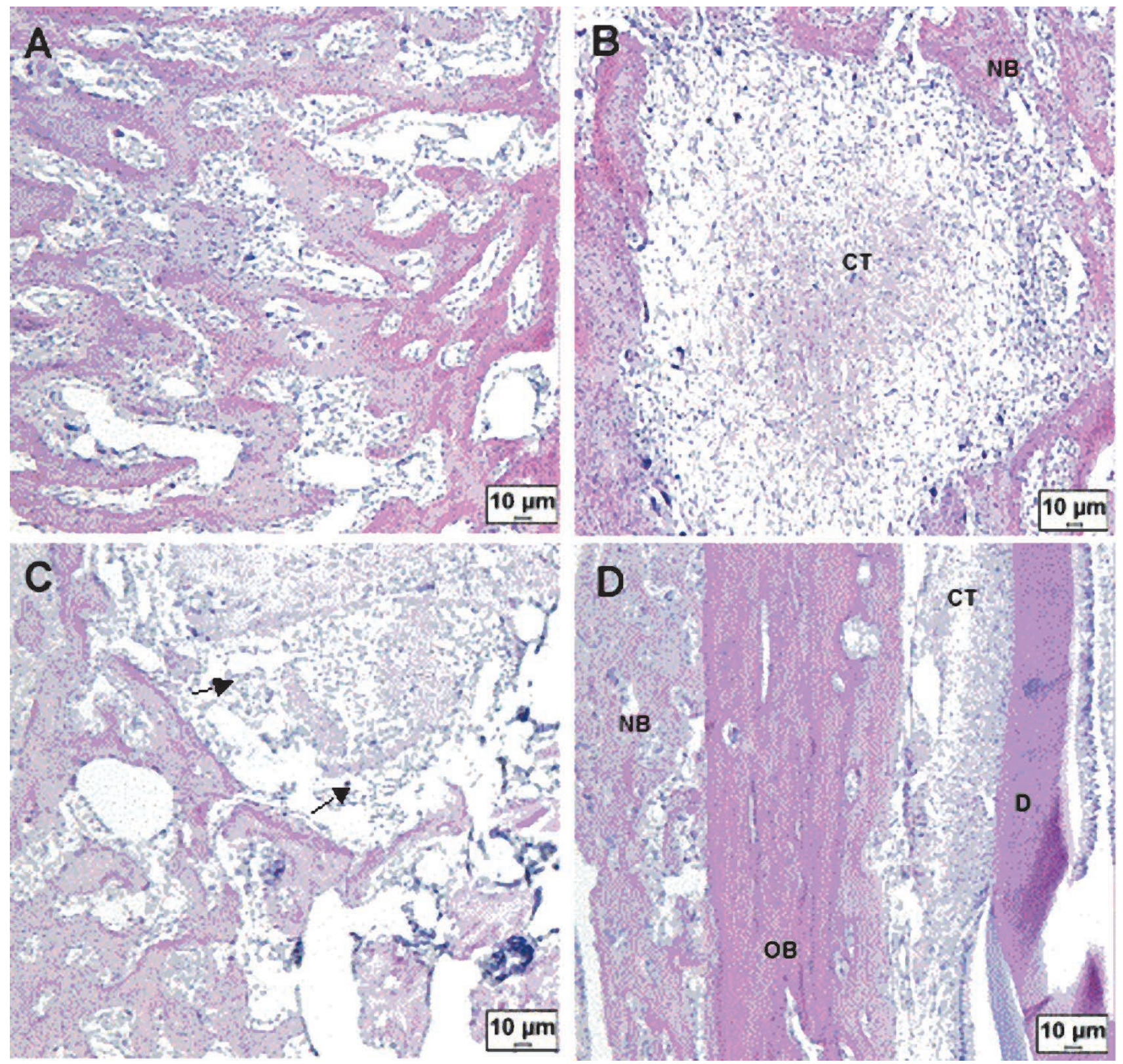

Fig. 2. A. Representative photomicrograph showing the more quantity of newly formed bone in the group IV (125X of original magnification, Hematoxylin-Eosin); B. Representative photomicrograph showing the centripetal bone healing process in the group III. This style of bone repair was found in all the groups. NB- newly formed bone, CT- connective tissue (125X of original magnification, Hematoxylin-Eosin); C. Representative photomicrograph showing the direction of the bone repair toward in the center of the lesion in the group II, also found in al the groups too. The arrows show the interface between the connective tissue and new bone tissue (125X of original magnification, Hematoxylin-Eosin); D. Representative photomicrograph showing newly formed bone (NB), connective tissue $(\mathrm{CT})$, old bone tissue (OB) and dentin tissue (D) in the group I (125X of original magnification, Hematoxylin-Eosin).

provoked by microorganisms after periradicular contamination. Exposure of the periradicular tissues to microorganisms results in the development of a periradicular lesion, thus, the goal of a root-end resection, preparation, and filling is to eliminate exposure of the periradicular tissues to the microorganisms in the root canal space. If the root-end preparation is inadequately prepared and sealed, failure will result. The Wistar rat experimental model used in this study has several advantages such as allowing a rapid healing period, animals easily lodged and fed, resistance to climatic variations, low cost, besides being routinely used in other experimental conditions involving bone reconstruction. 
Osteogenesis occurred in the groups that the MTA was applied, which it is according to Moretton et al., 2000. With intra-osseous implantation, the tissue reactions to the material subsided with time over a period of 12 weeks (Sousa et al., 2004). MTA (ProRoot) implantation in the mandible of guinea pigs resulted in bone healing and minimal inflammatory reactions (Saidon et al., 2003). The tissue reaction to MTA implantation was the most favorable reaction observed in both tibia and mandible of test animals, as in every specimen, it was free of inflammation. In the tibia, MTA was the material most often observed with direct bone apposition (Torabinejad et al., 1995c, 1998). In another study MTA was shown to be biocompatible and did not produce any adverse effect on microcirculation of the connective tissue (Masuda et al., 2005).

MTA is a powder that consists of fine hydrophilic particles that set in the presence of moisture. Hydration of the powder results in a colloidal gel with a $\mathrm{pH}$ of 12.5 that solidifies to a hard structure. The setting time for the cement is near from $4 \mathrm{~h}$ (Torabinejad et al., 1995c). Because of the slow setting time, the initial looseness of the MTA after mixing can make the material difficult to manage as a root-end filling material. Carrier-type devices are most often used for delivery of the MTA, but when the access or root-end preparation is small, the carrier-type devices can also be difficult to use. The MTA pellet forming and delivery technique overcome these difficulties. In this study, the MTA was handled and inserted quickly, isolately or combined with monoolein gel, in the bone defects. When using this technique, the MTA pellets should be placed as fast as possible into the root-end preparation because the small pellets will quickly dehydrate. When the MTA mixture is dry, it becomes crumbly and unmanageable.

Monoolein, a biodegradable polar lipid has no marked toxic effects (Ganem-Quintanar et al.) and depending on water content and temperature may form several phases, including reverse cubic and hexagonal ones. The reverse cubic phase of monoolein and water is formed at room temperature, and has been shown to accommodate and sustain the release of drugs with various physicochemical properties, including proteins and peptides (Lee \& Kellaway 2000 a, b; Lara et al. and Turchiello et al.). Thus, it becomes interesting to use this monoolein gel as a carrier for MTA. Besides all these considerations, monoolein gel has physical and chemical properties such as consistency, viscosity, biocompatibility to neighboring tissues, allowing MTA to remain in situ and to adhere to the bone defect walls. Furthermore, this gel is of low cost and easily synthesized from carbohydrates and fats (Nylander et al., 1996; Geraghty et al., 1997; Lee \& Kellaway, 2000b; Shah et al., 2001; Lee et al., 2005 and Boyd et al., 2006).

It was possible to observe deposition of calcified tissue over the MTA for specimens from the experimental groups, groups in that MTA was applied. This tissue was formed over and was continuous with the previous cementum, similar to that reported by Torabinejad et al. (1995a) and Pitt Ford et al. (1995a). The absence of inflammation in the majority of the specimens of the groups that MTA was applied confirms that this material is well tolerated and corroborates the findings of other authors after using MTA in bone tissue (Torabinejad et al., 1998), for root canal filling (Holland et al., 1999b), and for the sealing of contaminated root perforations (Pitt Ford et al., 1995a).

In one of the animals that was applied MTA combined with monoolein gel, it was observed an inflammatory response. This process was mainly in the proliferative phase, and it was possible to observe different amounts of mononuclear cells (lymphocytes, plasmocytes and macrographs), which permitted subjective classification of the severity of the reaction present. Regardless of the presence and severity of the inflammatory reaction, the apical barrier in the distal root of the molar was formed in this subject. The cellular response to MTA and mechanism of deposition for barrier formation are unknown and need further investigation. It is believed that the deposition of hard tissue over the material is related to features such as good sealing ability, biocompatibility, and alkaline $\mathrm{pH}$ (Torabinejad et al., 1995b, 1997); the presence of calcium and phosphate ions in its formulation (Torabinejad et al., 1995b); the capacity to attract blastic cells and to promote a favourable environment for cementum formation (Pitt Ford et al., 1995a, Torabinejad et al., 1995a); osseous and cementum conductive effect (Shabahang et al.; Moretton et al.); the stimulus to adhesion and cell proliferation (Koh et al., 1998), stimulus to expression of alkaline phosphatase by fibroblasts (Bonson et al., 2004) and osteocalcin and other interleukins by osteoblasts (Koh et al., 1997, Mitchell et al., 1999). It must be pointed out that bone resorption seen in animals was characterized by the presence of clastic cells. These observations, along with the presence of reparative cementum over the previously resorbed surfaces, indicate the evolution of the repair process.

The histological responses observed in this study indicate that the MTA is a reliable material and should be considered effective in bone periapical defects. Monoolein gel was capable to maintain the MTA in situ. 
FALCÃO-FILHO, H. B. L.; ISSA, J. P. M.; NASCIMENTO, C.; IYOMASA, M. M.; REGALO, S. C. H.; SIÉSSERE, S.; PEDRAZZI, V. \& PITOL, D. L. Histological evaluation of the bone repair using mineral trioxide aggregate combined to a material carrier. Int. J. Morphol., 25(4):789-796, 2007.

FALCÃO-FILHO, H. B. L.; ISSA, J. P. M.; NASCIMENTO, C.; IYOMASA, M. M.; REGALO, S. C. H.; SIÉSSERE, S.; PEDRAZZI, V.\& PITOL, D. L. Evaluación histológica del proceso de reparación ósea utilizando agregado trióxido mineral combinado a un material cargador. Int. J. Morphol., 25(4):789-796, 2007.

RESUMEN: El objetivo de este estudio fue presentar el gel de monoleína como un posible cargador para el MTA y verificar si es capaz de optimizar su acción. Los datos obtenidos fueron evaluados por métodos histomorfométricos y sometidos a análisis estadístico. El resultado histológico reveló que el MTA es un material efectivo para utilizarlo en defectos óseos periapicales y que el gel de monoleína es capaz de mantener el MTA in situ.

PALABRAS CLAVE: MTA; Gel de monoleína; Histomorfometría; Defecto perapical.

\section{REFERENCES}

Alhadainy, H. A. Root perforations. A review of literature. Oral.Surg. Oral.Med.Oral. Pathol., 78:368-74, 1994.

Al-Rabeah, E.; Perinpanayagam, H. \& MacFarland, D. Human alveolar bone cells interact with ProRoot and tooth-colored MTA. J. Endod., 32:872-5, 2006.

Bogaerts, P. Treatment of root perforations with calcium hydroxide and Super EBA cement: a clinical report. Int. Endod. J., 30:210-9, 1997.

Bonson, S.; Jeansonne, B. G. \& Lallier, T. E. Root-end filling materials alter fibroblast differentiation. J. Dent. Res., 83: 408-13, 2004.

Boyd, B.J.; Whittaker, D.V.; Khoo, S.M. \& Davey, G. Lyotropic liquid crystalline phases formed from glycerate surfactants as sustained release drug delivery systems. Int. J. Pharm., 309:218-26, 2006.

Economides, N.; Pantelidou, O.; Kokkas, A. \& Tziafas, D. Short-term periradicular tissue response to mineral trioxide aggregate (MTA) as root-end filling material. Int. Endod. J., 36:44-8, 2003.

Ganem-Quintanar, A.; Quintanar-Guerrero, D. \& Buri, P. Monoolein: a review of the pharmaceutical applications. Drug. Develop. Ind. Pharm., 26:809-20, 2000 .

Geraghty, P. G.; Attwood, D.; Collett, J. H.; Sharma H. \& Dandiker, Y. An investigation of the parameters influencing the bioadhesive properties of Myverol 1899/water gels. Biomaterials, 18:63-7, 1997.

Hartwell, G. R. \& England, M.C. Healing of furcation perforations in primate teeth after repair with decalcified freeze-dried bone: a longitudinal study. $J$. Endod., 19:357-61, 1993.
Holland, R.; De Souza, V.; Nery, M. J.; Otoboni Filho, J. A.; Bernabe, P. F. \& Dezan, E. Jr. Reaction of dogs' teeth to root canal filling with mineral trioxide aggregate or a glass ionomer sealer. J. Endod., 25:72830, $1999 b$.

Holland, R.; Filho, J.A.; deSouca, V.; Nery, M.J.; Bernabe, P. F. \& Junior, E. D. Mineral trioxide aggregate repair of lateral root perforations. J. Endod., 27:281-4, 2001.

Koh, E.T.; Torabinejad, M.; Pitt, Ford, T. R.; Brady, K. \& McDonald, F. Mineral trioxide aggregate stimulates a biological response in human osteoblasts. J. Biomed. Mater. Res., 37:432-39, 1997.

Koh, E. T.; McDonald, F.; Pitt Ford, T. R. \& Torabinejad, M. Cellular response to mineral trioxide aggregate. $J$. Endod., 24:543-7, 1998.

Lara, M. G.; Bentley, M. V. L. B. \& Collett, J. H. In vitro drug release mechanism and drug loading studies of cubic phase gels. Int. J. Pharm., 293:241-50, 2005.

Lee, S. J.; Monsef, M. \& Torabinejad, M. Sealing ability of a mineral trioxide aggregate for repair of lateral root perforations. J. Endod., 19:541-4, 1993.

Lee, J. \& Kellaway, I.W. Buccal permeation of [D-Ala2, D-Leu5] enkephalin from liquid crystalline phases of glyceryl monooleate. Int. J. Pharm., 195: 35-8, 2000 a.

Lee, J. \& Kellaway, I.W. Combined effect of oleic acid and polyethylene glycol 200 on buccal permeation of [D-Ala2, D-Leu5] enkephalin from a cubic phase of glyceryl monooleate. Int. J. Pharm., 204:137-44, $2000 b$.

Lee, S. J.; Kim, S. W.; Chung, H.; Park, Y. T.; Choi, Y. W.; Choi, Y. W.; Cho, Y. H. \& Yoon, M.S. Bioadhesive 
FALCÃO-FILHO, H. B. L.; ISSA, J. P. M.; NASCIMENTO, C.; IYOMASA, M. M.; REGALO, S. C. H.; SIÉSSERE, S.; PEDRAZZI, V. \& PITOL, D. L. Histological evaluation of the bone repair using mineral trioxide aggregate combined to a material carrier. Int. J. Morphol., 25(4):789-796, 2007.

drug delivery system using glyceryl monooleate for the intravesical administration of paclitaxel. Chemotherapy, 51: 311-8, 2005.

Lemon, R. R. Nonsurgical repair of perforation defects. Internal matrix concept. Dent. Clin. North. Am., 36:43957, 1992 .

Masuda, Y. M.; Wang, X.; Hossain, M. et al. Evaluation of biocompatibility of mineral trioxide aggregate with an improved rabbit ear chamber. J. Oral. Rehabil., 32:14550,2005

Mitchell, P. J.; Pitt Ford, T. R.; Torabinejad, M. \& McDonald, F. Osteoblast biocompatibility of mineral trioxide aggregate. Biomaterials, 20:167-73, 1999.

Moretton, T. R.; Brown, C. E.; Legan, J. J. \& Kafrawy, A.H. Tissue reactions after subcutaneous and intraosseous implantation of mineral trioxide aggregate and ethoxybenzoic acid cement. J.Biomed.Mater.Res., $52: 528-33,2000$.

Nylander, T.; Mattisson, C.; Razumas, V.; Miezis, Y. \& Hakansson, B. A study of entrapped enzyme stability and substrate diffusion in a monglyceride-based cubic liquid crystalline phase. Coll. Surf. A: Phys. Eng. Asp., 114:311-20, 1996.

Osorio, R. M.; Hefti, A.; Vertucci, F. J. \& Shawley, A.L. Cytotoxicity of endodontic materials. J.Endod., 24:916,1998.

Oviir, T.; Pagoria, D.; Ibarra, G. \& Geurtsen, W. Effects of gray and white mineral trioxide aggregate on the proliferation of oral keratinocytes and cementoblasts. J. Endod., 32:210-13, 2006.

Pitt Ford, T. R.; Torabinejad, M.; Abedi, H. R.; Bakland, L. K. \& Kariyawasam, S.P. Using mineral trioxide aggregate as a pulp-capping material. J. Am. Dent. Assoc., 127:1491-4, 1996.

Pitt Ford, T. R.; Torabinejad, M.; Mckendry, D. J.; Hong, C. U. \& Kariyawasam, S. P. Use of mineral trioxide aggregate for repair of furcal perforations. Oral. Surg. Oral.Med.Oral.Pathol.Oral.Radiol.Endod., 79:75663, 1995.

Regan, J. D.; Gutmann, J. L. \& Witherspoon, D.E. Comparison of Diaket and MTA when used as rootend filling materials to support regeneration of the periradicular tissues. Int. Endod. J., 35:840-47, 2002.
Saidon, J.; He, J.; Zhu, Q.; Safavi, K. \& Spangberg, L.S. Cell and tissue reactions to mineral trioxide aggregate and Portland cement. Oral. Surg. Oral. Med. Oral. Pathol. Oral. Radiol. Endod., 95:483-9, 2003.

Schwartz, R. S.; Mauger, M.; Clement, D. J. \& Walker, W.A. Mineral trioxide aggregate: a new material for endodontics. J. Am. Dent. Assoc., 130:967-75, 1999.

Shabahang, S.; Torabinejad, M.; Boyne, P. P.; Abedi, H.; McMillan, P. A comparative study of root-end induction using osteogenic protein-1, calcium hydroxide, and mineral trioxide aggregate in dogs. J.Endod., 25:1-5, 1999.

Shah, J. C.; Dadhale, Y. \& Chilukuri, D. M. Cubic phase gels as drug delivery systems. Adv. Drug. Deliv. Rev., 47: 229-50, 2001.

Sousa, C. J.; Loyola, A. M.; Versiani, M. A.; Biffi, J.C.; Oliveira, R. P. \& Pascon, E.A. A comparative histological evaluation of the biocompatibility of materials used in apical surgery. Int. Endod.J., 37:73848, 2004.

Tittle, K.; Farley, J.; Linkhart, T. \& Torabinejad, M. Apical closure induction using bone growth factors and mineral trioxide aggregate. J. Endod., 22:198-203, 1996.

Torabinejad, M. \& Chivian, N. Clinical applications of mineral trioxide aggregate. J. Endod., 25:197-205, 1999.

Torabinejad, M.; Hong, C.U.; Lee, S. J.; Monsef, M. \& Pitt Ford, T. R. Investigation of mineral trioxide aggregate for root end filling in dogs. J. Endod., 21:603-08, 1995a.

Torabinejad, M.; Hong, C. U. \& Pitt Ford, T. R. Physical properties of a new root end filling material. J. Endod., 21: 349-53, 1995b.

Torabinejad, M.; Hong, C. U. \& Pitt Ford, T. R.; Kaiyawasam, S.P. Tissue reaction to implanted superEBA and mineral trioxide aggregate in the mandible of guinea pigs: a preliminary report. J. Endod., 21:569$71,1995 \mathrm{c}$

Torabinejad, M.; Hong, C. U.; Pitt Ford, T. R. \& Kettering, J. D. Cytotoxicity of four root end filling materials. J. Endod., 21: 489-92, 1995d.

Torabinejad, M.; Pitt Ford, T. R.; Abedi, H. R.; Kariyawasam, S. P. \& Tang, H. M. Tissue reaction to implanted root-end filling materials in the tibia and mandible of guinea pigs. J. Endod., 24: 468-71, 1998. 
FALCÃO-FILHO, H. B. L.; ISSA, J. P. M.; NASCIMENTO, C.; IYOMASA, M. M.; REGALO, S. C. H.; SIÉSSERE, S.; PEDRAZZI, V. \& PITOL, D. L. Histological evaluation of the bone repair using mineral trioxide aggregate combined to a material carrier. Int. J. Morphol., 25(4):789-796, 2007.

Turchiello, R. F.; Vena, F. C. B.; Maillard, P. H.; Souza, C. S.; Bentley, M. V. L. B. \& Tedesco, A.C. Cubic phase gel as a drug delivery system for topical application of 5-ALA, its ester derivatives and $\mathrm{m}$-THPC in photodynamic therapy (PDT).J.Photochem. Photobiol., 70:1-6, 2003.

Weibel, E.R.; Kistler, G. S. \& Scherle, W.F. Practical stereological methods for morphometric cytology. $J$. Cell. Biol., 30:23-38, 1966.

Zhu, Q.; Haglund, R.; Safavi, K.E. \& Spangberg, L.S. Adhesion of human osteoblasts on root-end filling materials. J. Endod., 26:404-6, 2000.
Correspondence to:

Dr. João Paulo Mardegan Issa

Faculdade de Odontologia de Ribeirão Preto - USP

Departamento de Morfologia, Estomatologia e Fisiologia

CEP: $14040-904$

Av. Café $\mathrm{S} / \mathrm{N}$

Ribeirão Preto, SP

BRASIL

Phone: +55-16-36024095

Fax: +55-16-36330999

E-mail: jpmissa@forp.usp.br

Received: 20-05-2007

Accepted: 24-08-2007 